BIP: Jurnal Bahasa Indonesia Prima

Vol. 3, No. 2, 2021, September 2021, PP.

\title{
PENGENALAN ICE BREAKING DALAM MENINGKATKAN SEMANGAT BELAJAR SISWA
}

\author{
Sugito $^{1}$, Dwi Lestari ${ }^{2}$, Yayang Azrina ${ }^{3}$, Ade Tri Novika ${ }^{4}$ \\ STKIP Pangeran Antasari \\ Corresponding Author: sugitotami@gmail.com
}

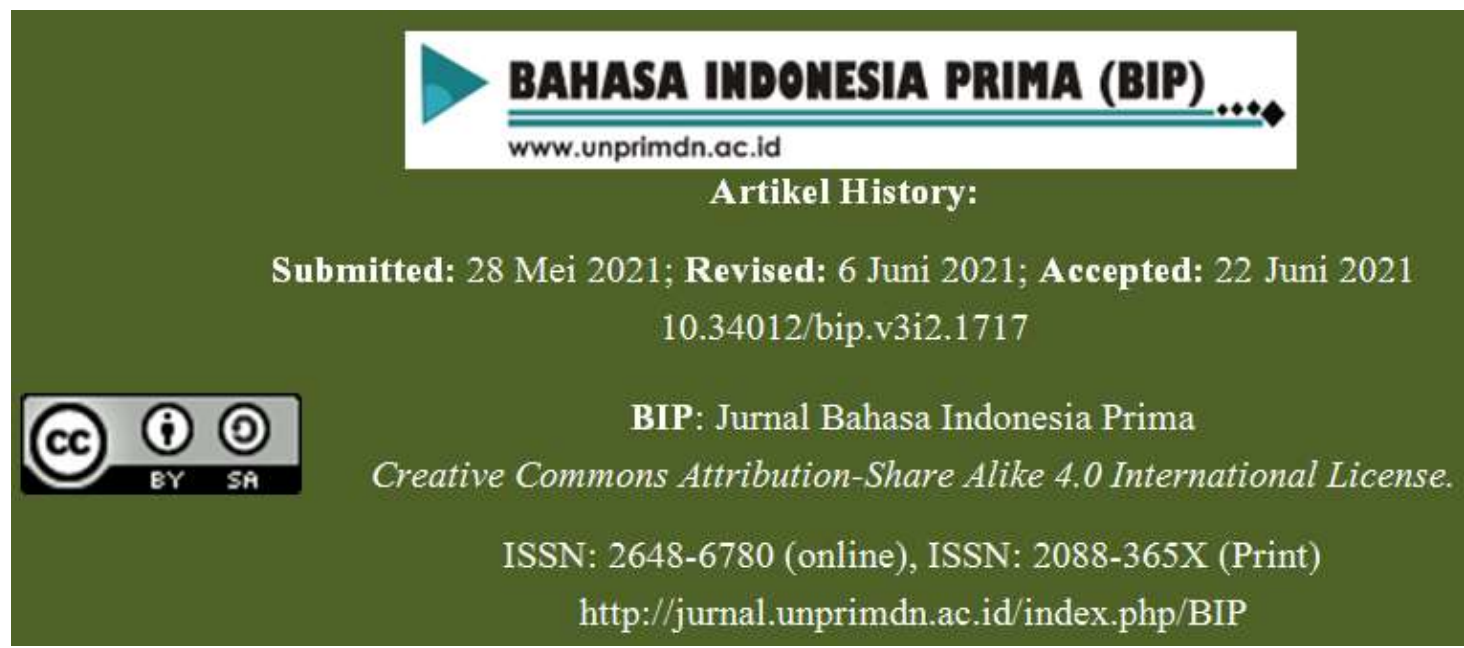

Abstrak-Proses kegiatan pembelajaran di kelas tidak terlepas dari peran guru di dalamnya. Dimana guru sebagai pendidik sangat mempengaruhi proses kegiatan belajar mengajar di kelas. Tujuan pembelajaran menjadi salah satu patokan guru dalam mengajarkan peserta didik, apabila tujuan pembelajaran belum dapat tercapai maka guru harus mengevaluasi kembali proses kegiatan pembelajaran. Tentu hal ini tidaklah mudah, guru harus mengetahui dimana kesalahan saat pembelajaran berlangsung. Banyak yang menjadi faktor internal maupun eksternal dalam menghambat keberhasilan belajar peserta didik. Salah satu faktor penghambatnya adalah faktor eksternal, yaitu lingkungan belajar peserta didik. Jika keadaan disekitar tidak mendukung terjadinya proses pembelajaran, maka hal tersebut akan mempengaruhi aspek psikologis anak. Selanjutnya akan membuat peserta didik kelelahaan ataupun cenderung merasa bosan dalam mengikuti pembelajaran, sehingga pembelajaran yang disampaikan guru tidak dapat diterima dengan baik. Dari beberapa permasalahan tersebut terdapat solusi yang dianggap tepat yaitu memasukkan ice breaking di dalam proses kegiatan belajar mengajar. Artikel ini akan menjelaskan tentang pengenalan ice breaking dan bagaimana ice breaking dapat meningkatkan semangat siswa dalam belajar.

Kata Kunci: belajar, bosan, ice breaking.

\section{A. Pendahuluan}

Pendidikan merupakan usaha etis yang dilakukan demi mewujudkan tujuan institusional. Sehingga apabila terjadi masalah dalam proses kegiatan pembelajaran maka berpengaruh terhadap tujuan institusional yang telah ditetapkan. Dalam siklus ini guru berperan penting dalam membantu mewujudkan tujuan pembelajaran di kelas. Sebelum masuk ke kelas untuk mengajar peserta didik, guru dituntut agar mampu merencanakan, melaksanakan pembelajaran, dan mengevaluasi keberhasilan dalam pembelajaran. Keberhasilan dari proses kegiatan pembelajaran berada ditangan guru, mulai dari keberhasilan tujuan institusional sampai kepada tujuan 
orangtua peserta didik. Begitulah besarnya pengaruh guru dalam dunia pendidikan, sehingga guru harus mempersiapkan dengan mateng apa saja yang menjadi kepentingan sebelum kegiatan belajarmengajar berlangsung seperti merencanakan, mengevaluasi dan membimbing peserta didik dalam proses pembelajaran.

Berdasarkan hasil pengamatan yang kami laksanakan di sekolah MIS Modern Terpadu Az-Zaky, strategi belajarmengajar yang dilakukan guru sudah sangat bagus, hanya saja jika ditambah dengan kegiatan ice breaking sebelum memulai kegiatan pembelajaran, kami sebagai tim peneliti yakin bahwa pembelajaran akan terasa lebih menyenangkan.

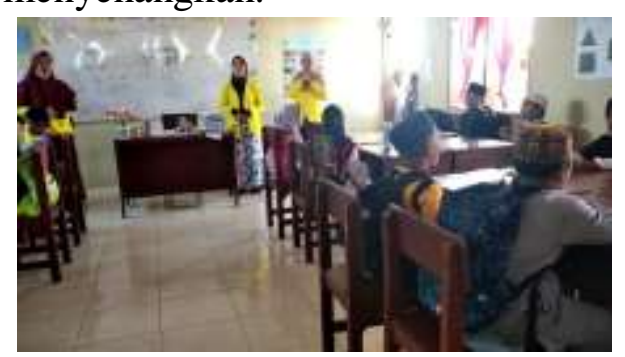

Gambar 1 Keadaan peserta didik pada saat mengikuti kelas khusus Ice Breaking

Pada saat tim turun melakukan observasi kebeberapa kelas, kami tidak banyak menemukan guru yang mengajar dengan memanfaatkan kegiatan ice breaking di dalam proses KBM-nya. Informasi tersebut kami peroleh dengan mewancarai beberapa guru yang ada di dalam kelas, bahwa benar mereka jarang menggunakan ice breaking di dalam pembelajaran.

Hal inilah yang mendasari tim untuk membantu guru dalam mengembangkan dan mensosialisasikan manfaat penerapan ice breaking di dalam pembelajaran. Maka dari itu kami mengangkat judul "Pengenalan Ice Breaking dalam
Meningkatkan Semangat Belajar Siswa" pada artikel ilmiah ini.

Sesuai dengan latar belakang masalah serta mengacu pada tujuan penelitian ini, maka masalah dalam penelitian ini dapat dirumuskan sebagai berikut:

1. Apakah semangat belajar siswa dapat meningkat melalui kegiatan ice breaking di dalam kelas?

2. Bagaimana hasil Penerapan pengenalan ice breaking pada kegiatan pembelajaran di kelas?

Tujuan dari penelitian ini sebagai berikut:

1. Untuk mengetahui peningkatan semangat belajar siswa melalui kegiatan ice breaking di dalam kelas.

2. Memaparkan hasil penerapan pengenalan ice breaking pada kegiatan pembelajaran di kelas.

Adapun manfaat dari penelitian ini adalah:

1. Untuk merencanakan perbaikan dan penyempurnaan dalam melaksanakan KBM di kelas.

2. Dapat memberikan sumbangan pemikiran kepada para pendidik dalam meningkatkan semangat belajar siswa dalam kelas.

\section{B. Metode Penelitian}

Proses belajar-mengajar didefenisikan sebagai usaha guru dalam melaksanakan pembelajaran di kelas yang harus dilakukan dengan dua arah, artinya pembelajaran yang disampaikan guru akan ditanggapi siswa secara timbal balik dan siswa turut berperan aktif selama proses berjalannya pembelajaran. Ada tiga komponen utama yang harus diperhatikan dalam proses belajar mengajar menurut Loree yang dikutip oleh Achmad Fanani (2010) dalam jurnalnya yaitu komponen S (stimuli), $\mathrm{O}$ (organismic), dan $\mathrm{R}$ 
(response). Respon dalam hal ini berkaitan denag hasil belajar yang diharapkan, yaitu perilaku kognitif, perilaku afektif, dan perilaku psikomotor.

Pada kutipan Fitrah dalam Jurnalnya yang berjudul Belajar dan Pembelajaran (2017) menyatakan dalam kegiatan belajar dan mengajar, peserta didik adalah subjek dan objek dari kegiatan pendidikan. Oleh karena itu, makna dari proses pengajaran adalah kegiatan belajar peserta didik dalam mencapai suatu tujuan pengajaran. Tujuan pengajaran akan dicapai apabila peserta didik berusaha secara aktif untuk mencapainya. Keaktifan anak didik tidak hanya dituntut dari segi fisik, tetapi juga dari segi kejiwaan. Apabila hanya dari segi fisik saja yang aktif dan mentalnya tidak aktif, maka tujuan dari pembelajaran belum tercapai. Hal ini sama saja dengan peserta didik tidak belajar, karena peserta didik tidak merasakan perubahan dalam dirinya. Belajar pada hakikatnya adalah suatu "perubahan" yang terjadi dalam diri seseorang setelah melakukan aktivitas belajar.

\section{Hasil dan Pembahasan}

Sebelum mengajar guru harus mempersiapkan segala keperluan dalam kegiatan pembelajaran, seperti penentuan strategi, metode, model dan media yang digunakan untuk keberhasilan proses pembelajaran. Akan tetapi, dalam praktiknya guru sering sekali tidak mempersiapkan segala sesuatu yang menjadi kewajibannya. Seperti hanya menggunakan metode ceramah dalam mengajar peserta didik.

Guru beranggapan bahwa dengan mengajar sampai selesai maka kewajibannya sudah terselesaikan, tanpa memperhatikan lingkungan belajar (kondisi siswa saat sedang belajar) sehingga terkadang proses pembelajaran menghasilkan kondisi yang kurang maksimal dan menyebabkan tujuan pembelajaran sulit tercapai.

Lingkungan belajar dengan dihadapkan pada peserta didik yang tentunya memiliki karakteristik berbeda-beda, tentu moodnya dalam belajar pun berbeda. Dalam hal ini guru selalu menganggap semua siswa sama dan langsung memulai pembelajaran yang alhasil membuat kondisi belajar dipenuhi ketegangan dan membuat siswa kurang merasa nyaman dan semangat dalam pelaksanaan kegiatan belajar mengajar di kelas. Proses ini akan terulang setiap hari dan lama kelamaan peserta didik bisa merasa bosan untuk mengikuti pembelajaran. Jika hal ini dibiarkan terus menerus maka akan merugikan kedua belah pihak, yaitu siswa dan guru bahkan juga dapat merugikan pihak institusional.

Proses pembelajaran di kelas terjadi secara berulang-ulang setiap hari. Dengan kondisi ini tak jarang membuat peserta didik merasa bosan, lelah ataupun keletihan, kecemasan, ketakutan dan kejenuhan. Di samping itu, guru juga kurang memperhatikan behavior peserta didik pada saat pergantian jam pelajaran. Tanpa memperhatikan kejenuhan siswa, guru tetap melanjutkan pemberian materi pada mata pelajaran yang diampunya. Hal ini tentu saja menjadi kendala terhadap keberhasilan proses pembelajaran.

Menurut Dryden \& Vos (2000) dikutip oleh Darmansyah (2010:11) belajar akan efektif bila proses pembelajaran dilaksanakan dengan suasana yang menyenangkan (joyfull learning). Ada beberapa hal yang membuat kondisi suasana di kelas menjadi menyenangkan, yaitu guru menggunakan berbagai variasi, model dan teknik, menggunakan media yang menarik dan menantang peserta didik, memahami kondisi fisik peserta 
didik sebelum memulai pembelajaran. Permainan dalam pembelajaran juga sangat membantu untuk membuat kelas jadi hangat dan menyenangkan. Guru juga bisa melaksanakan proses pembelajaran sambil bermain dengan permainanpermainan yang berhubungan dengan konteks pembelajaran.

Menurut KBBI Permainan adalah sesuatu yang digunakan untuk bermain, barang atau sesuatu yang dipermainkan. Menurut Agustina (2015:2), "Game atau permainan adalah suatu cara belajar dengan menganalisa dengan sekelompok pemain maupun indvidual dengan menggunakan stragtegi-strategi yang rasional."

Bermain game merupakan sebuah kegiatan yang sering dilakukan anak-anak sebagai sarana untuk mengisi waktu luang. Jadi, dengan bermain game peserta didik juga bisa meningkatkan kecerdasan kognitifnya seperti kemampuan menghitung, kemampuan mengenal bentuk-bentuk benda. Sehingga dapat dimanfaatkan oleh guru sebagai strategi belajar-mengajar di dalam kelas, dengan harapan mampu mengajak siswa belajar dalam keadaan semangat dan tidak merasa jenuh dalam proses KBM.

Era semakin maju, maka guru tidak bisa hanya mengandalkan sesuatu yang ada saja. Guru juga harus mampu meningkatkan kemampuannya untuk lebih up to date di masa pekembangan IPTEK. Pada zaman ini peserta didik lebih handal dalam penggunaan gudget, maka guru harus selangkah lebih maju di depan untuk mempelajari perkembangan yang ada agar tidak tertinggal dari peserta didik. Guru harus mampu meningkatkan kompetensi dan kualitas dirinya. Guru harus mampu beradaptasi dengan dunia sekarang.
Ice breaking merupakan opening pembelajaran zaman sekarang yang dapat membuat suasana kelas menyenangkan. Menyenangkan bukan berarti guru dan siswa di dalam kelas hanya bermain dan tertawa saja. Menyenangkan dalam artian siswa di kelas dapat merasa enjoy, tidak merasa terintimidasi, atau tertekan dalam pembelajaran. Hal ini akan membuat kehadiran seorang guru begitu dinantikan di dalam kelas. Dengan adanya ice breaking siswa akan merasa betah di dalam kelas.

Ice breaking merupakan salah satu rutinitas yang berhasil memecahkan kejenuhan, kebekuan dan ketakutan yang terjadi di dalam kelas. Sehingga proses pembelajaran kembali semangat dan kembali seperti keadaan semula (lebih kondusif), siswa juga akan mudah menerima perkataan yang disampaikan guru.

Istilah ice breaking berasal dari dua kata asing, yaitu ice yang berarti es yang berarti memiliki sifat kaku, dingin, dan keras, sedangkan breaking berarti memecahkan. Arti harfiah ice breaking adalah 'pemecah es'. Jadi, ice breaking bisa diartikan sebagai usaha untuk memecahkan atau mencairkan suasana yang kaku seperti es agar menjadi lebih nyaman mengalir dan santai. Hal ini bertujuan agar materi-materi yang disampaikan dapat diterima. Siswa akan lebih dapat menerima materi pelajaran jika suasana tidak tegang, santai, nyaman, dan lebih bersahabat. (Sunarto, 2012:1).

Ice breaking menurut M.Said(2010:1) mengatakan yang dimaksud ice breaking adalah permainan atau kegiatan yang berfungsi untuk mengubah suasana kebekuan dalam kelompok.

Ice breaking dapat dilakukan dengan berbagai bentuk aktivitas, ada yang 
dilakukan dengan cara bermain game, tepuk - tepuk inovasi, dalam bentuk cerita lucu, tebakan berhadiah.

Secara umum fungsi ice breaking adalah:

1. Perkenalan;

2. Menghilangkan kejenuhan pada diri peserta;

3. Pemanasan sebelum kegiatan di luar ruangan;

4. Pengisi waktu jeda;

5. Meningkatkan semangat dan antusiasme peserta dalam mengikuti kegiatan pembelajaran;

6. Pengantar sebelum materi;

7. Mengakrabkan peserta didik.

Ada beberapa bentuk ice breaking sesuai unggahan ronapresentasi.com (pada tanggal 11, bulan Juni, tahun 2014), antara lain:

Lelucon adalah bentuk pemecah kebekuan yang paling popular di kalangan banyak orang. Namun juga bentuk pemecah kebekuan yang paling sulit dilakukan dan cukup berbahaya untuk dilakukan. Karena untuk bisa melucu itu tidak mudah, apalagi bagi orang - orang yang tidak mempunyai humor yang tinggi.

\section{Games atau permainan}

Games saat ini juga menjadi alternatif guru, dosen, pelatih dan pembicara untuk memecah kebekuan dan membuat suasana menjadi menyenangkan.

Perlu diketahui bahwa ada perbedaan antara bermain game untuk bersenang senang dan bermain game untuk keperluan belajar. Bermain game sekedar untuk kesenangan tidak dimaksudkan untuk mencapa tujuan pembelajaran. Mungkin banyak orang mengatakan bahwa ia mempelajari banyak hal dari game yang dimainkan. Namun, pelajaran yang didapatkan banyak dampak pengiring semata dan bukan merupakan tujuan utama sebuah game. Game untuk belajar mengandaikan bahwa game memang sengaja didesain untuk mencapai tujuan pembelajaran tertentu atau disebut gamebased learning. Guru melakukan game sebagai sebuah kegiatan pembelajaran. (Setyawan,2015)

\section{Lagu atau nyanyian yang disertai gerak tubuh}

Lagu atau nyanyian ini juga banyak digunakan dalam ice breaking. Cara bermainnya yaitu dengan cara memutar lagu lalu mengajak audiens bernyanyi atau bergerak bersama-sama. Guru juga bisa merancang gerakan atau koreo yang mendukung nyanyian atau lagu dan dimasukkan ke materi pembelajaran.

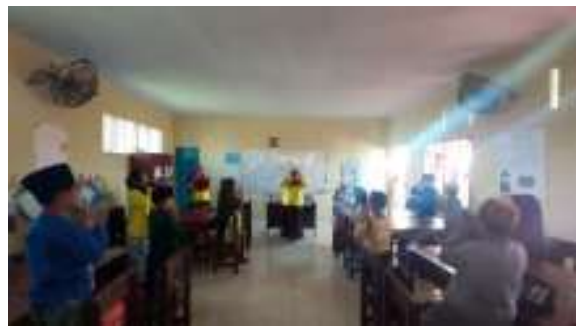

Gambar 2 Keadaan kelas dan suasana kelas pada saat pelaksanaan ice breaking oleh Mahasiswa STIPPA

Pelaksanaan ice breaking yang kami praktikkan pada kegiatan diatas yaitu bentuk ice breaking yang ketiga, yaitu ice breaking yang dilakukan dengan lagu atau nyanyian disertai gerakan tubuh. Ice breaking yang kami terapkan pada gambar 2, yaitu 'sentuh tubuh' dilakukan sambil bernyanyi sesuai arahan instruktur. Contoh permainannya yaitu dengan bernyanyi lagu "Pegang Apa Sekarang" instruktur memberi arahan pegang mata, tetapi instruktur memegang telinga sebagai pengecoh peserta didik untuk mengetahui tingkat kefokusannya.

Dari pelaksanaan kegiatan tersebut kami dapat melihat bagaimana antusias peserta didik dalam mengikuti arahan kami untuk melakukan kegiatan ice breaking 
BIP: Jurnal Bahasa Indonesia Prima Vol. 3, No. 2, 2021, September 2021, PP.

dengan penuh semangat. Peserta didik juga memberikan respon yang baik dalam melakukan ice breaking tersebut, sehingga apabila diaplikasikan ke dalam pembelajaran di kelas, maka pembelajaran akan lebih menyenangkan dan mampu meningkatkan suasana pembelajaran menjadi lebih baik.

Setelah melaksanakan kegiatan ini, kami sangat berharap guru mampu lebih kreatif dan ada kemauan untu menerapkan ice breaking di kelas. Selain dari beberapa ice breaking yang kami perkenalkan pada saat penelitian, guru juga bisa menerapkan ice breaking yang ada di Youtube. Sudah begitu banyak ice breaking yang ada di Youtube, sehingga menjadikan guru lebih mudah untuk mencontohnya sebagai referensi dalam mengajarkannya di dalam kelas. Tinggal lagi bagaimana kemauan guru dalam menggunakan dan menerapkannya di dalam kelas. Sebaliknya jika guru tidak ada kemauan maka hal apapun akan terasa sulit.

\section{Kesimpulan}

Dari uraian di atas dapat disimpulkan bahwa:

1. Dengan penggunaan ice breaking, pembelajaran di kelas menjadi lebih hangat dan menyenangkan, sehingga menambah semangat siswa untuk antusias kembali dalam mengikuti KBM di kelas.

2. Hasil pengenalan ice breaking yang kami lakukan disambut baik oleh guru dan peserta didik, sehingga guru perlu memasukkan kegiatan ice breaking di dalam kegiatan pembelajaran di kelas.

\section{Daftar Pustaka}

M. Said. 2010. 80+ Ice Breaker GamesKumpulan Permainan Penggugah Semangat. Yogyakarta: Andi Offset. hlm.1

Sunarto. 2012. Ice Breaker dalam Pembelajaran Aktif. Surakarta: Yuman Pressindo. hlm. 1

Syafriafdi, N.Dr. . 2020. Menjadi Guru Hebat di Era Revolusi Industri 4.0. Yogyakarta: CV Budi Utama. hlm. 78

Batista.Y. 2012. Games Indoor-Outdoor Paling Gress \& Trik Modifikasi.

Yogyakarta: Jogja Bangkit Publisher. hlm. 1

Setyawan,S. 2015. Kelas Asyik Dengan Games. Jakarta: PT Gramedia 